\title{
Geometry and flow conditions of subglacial water at South Cascade Glacier, Washington State, U.S.A.; an analysis of tracer injections
}

\author{
ANDREW G. Fountain \\ U.S. Geological Survey, P.O. Box 25046, MS 412, Denver, Colorado 80225, U.S.A.
}

\begin{abstract}
Tracers were injected into South Cascade Glacier to determine the flow condition and geometry of the subglacial water system. Results indicate that two distinct drainage basins on the glacier feed the two main streams flowing from the glacier. In the largest basin, two parallel drainage networks exist, one englacial and the other subglacial. The englacial system is an arboresecent network of conduits, whereas the subglacial system is a distributed flow system. Both systems connect to a single subglacial conduit which appears as a stream at the glacier's terminus. The comparison between the travel time of the tracers and stream discharge indicated that the single conduit was pressurized in July and partly filled in August and September.

To estimate the flow geometry (e.g. path length, flow depth and velocity), the advection-diffusion equation was formulated to express the water velocity as a function of water depth. Longitudinal dispersion of the tracer was calculated from the shear in longitudinal water velocity. Results indicate that the flow is very wide compared to its depth and that the path is sinuous. The estimated flow speed in the conduits is an order of magnitude larger than the measured speed through the glacier, indicating that other flow processes, probably englacial, route the water much more slowly.

The other, smaller, basin drains the water from the surface to the subglacial distributed flow system. Based on the travel time of the individual concentration peaks, the water could be flowing through a linked-cavity system or interconnected bands of highly permeable debris separated by zones of less permeability.
\end{abstract}

\section{INTRODUCTION}

The injection of tracers into sub-surface flow provides information about flow paths from tracer location, flow speed from the travel time and passage geometry from the dispersion. This information, when taken together, provides insight into the hydraulic processes of subsurface flow. Most previous investigations using tracers have focused on the travel time of the tracer to infer the flow conditions (Krimmel and others, 1973; Lang and others, 1979; Collins, 1982; Burkimsher, 1983). Others have focused on dispersion (Behrens and others, 1975). One problem in using these methods is the difficulty in translating the results into physical measures such as channel cross-sectional shape or path length. One recent advance in this regard is the attempt by Brugman (1986) to relate the dispersion of the tracer to a length scale characteristic of the flow geometry. This approach has been used by Seaberg and others (1988) and Willis and others (1990) to discern whether the flow system is distributed as in a linked cavity system or channelized in conduit flow.

The study presented here differs from previous tracer studies in that the results are compared to a model in which the velocity and dispersion result from the mechanics of the flow rather than as adjustable parameters. This approach allows an estimate of path length, water depth and channel width. The flow condition of the conduit, whether it is pressurized or partly filled, can be determined from the relation between travel time of the tracer and water discharge.

\section{SITE LOCATION AND FIELD METHODS}

The study site was South Cascade Glacier, a small, temperate glacier on the western slope of the crest of the North Cascade Range in Washington State, U.S.A. The glacier is $3.4 \mathrm{~km}$ long, a maximum of about $1 \mathrm{~km}$ wide and covers an area of about $2.5 \mathrm{~km}^{2}$ (Fig. 1). Three streams drained the glacier and the stage of each stream was recorded during 1986, and only the two largest streams were monitored in 1987. Discharge measurements were periodically made on each stream using a rotatingcup velocity meter. The details of these and other streamflow measurements are summarized in Fountain (in press b).

The time required for a tracer to travel completely 


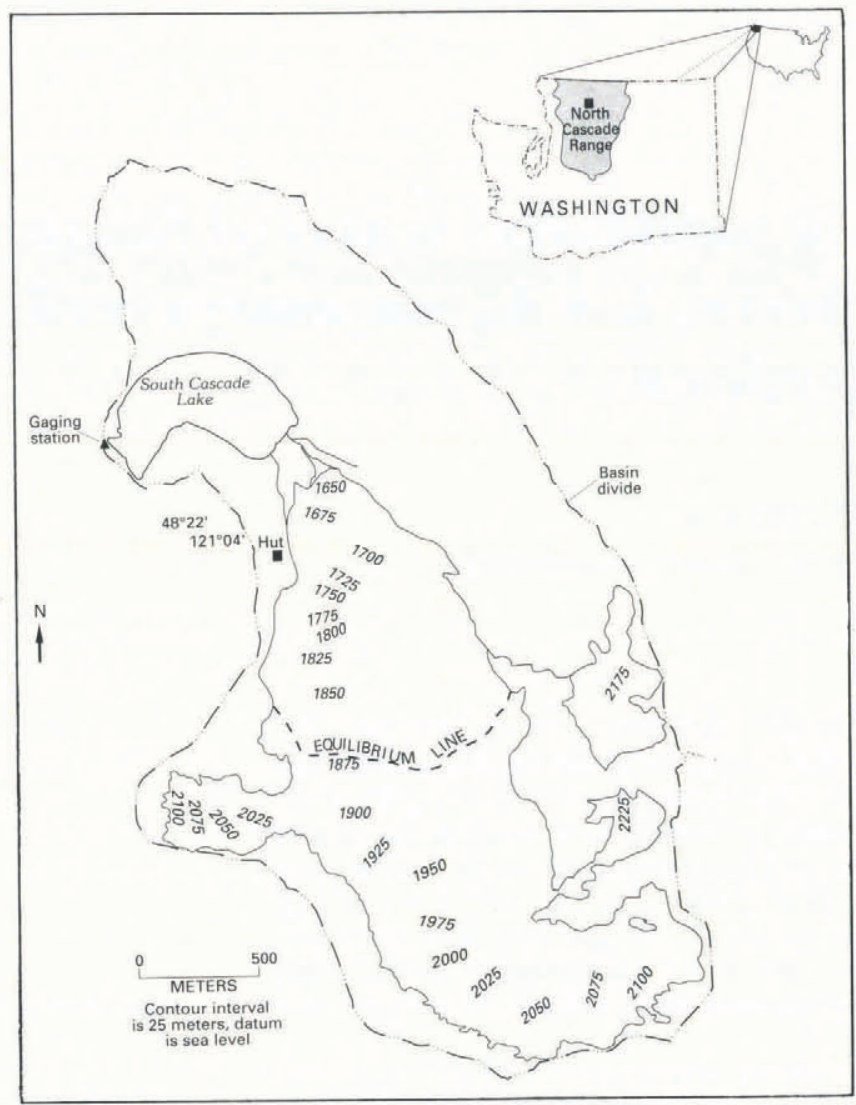

Fig. 1. South Cascade Glacier, September 1985. The shaded region is the non-glacierized part of the basin.

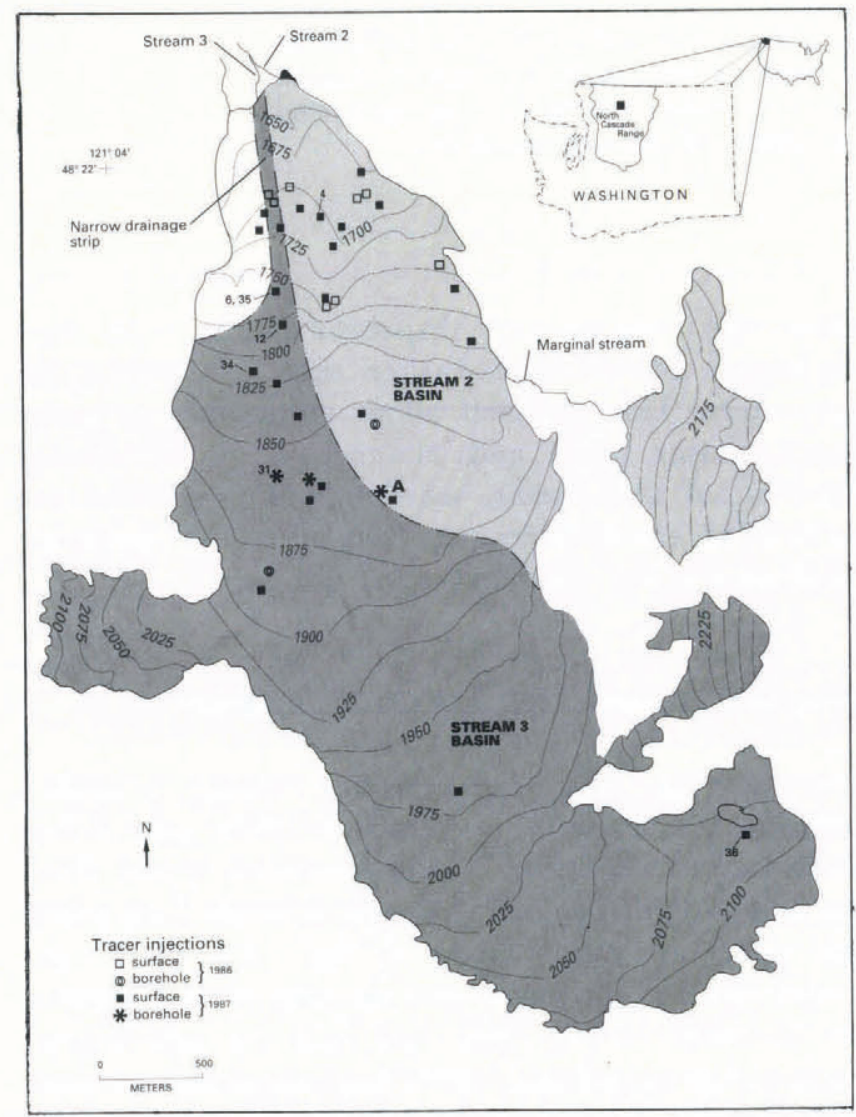

Fig. 2. Locations of tracer injections and inferred drainage basins. " $A$ " indicates the location of paired surface and borehole injections. Stream 2 drains through a small proglacial pond. through a glacier can be a few hours to several weeks depending on location of injection and time of year. To maximize the number of injections, two non-interfering tracers were used: tinopal CBS-X (Ciba-Geigy Corp.) and rhodamine WT (Crompton and Knowles Corp."). Tinopal is an optical brightener used in laundry detergents; its peak excitation and emission wavelengths are in the near-ultra violet range at 370 and $430-435 \mathrm{~nm}$, respectively (written communication from Ciba-Geigy Corp., Greensboro, N.C., 1987). Tinopal CBS-X has been used previously as a tracer (Gaspar, 1987) and the AMS variety of tinopal has been used in glaciers (Brugman, 1986). Rhodamine WT is a commonly used tracer often used in glacier studies; its peak excitation and emission wavelengths are 558 and $582 \mathrm{~nm}$, respectively. Although sorption effects of rhodamine WT are well known (Bencala and others, 1983; Brugman, 1986), they were not explicitly examined during this study. The sorption properties of tinopal are unknown.

The two tracers were each detected by a different fluorometer. The fluorometers were connected in series, and as the water flowed from one instrument into the next, the concentration of the tracers was continuously monitored. Water flowed from the streams, through plastic pipe, to the instrument site where it entered a switching device that routed the water from one stream at a time through the fluorometers. Fortunately, the slope of the proglacial terrain was sufficient to drive the water through the pipe by gravity, eliminating the need for pumps. A solid-state data logger controled the switching device and recorded the fluorometric data. Details of the instrument arrangement can be found in Fountain (in press a).

There was no measurable effect of the tinopal CBS-X concentrations on the fluorometer set up for rhodamine WT, although there was a measurable effect on the fluorometer set up for tinopal from the rhodamine at concentrations starting at $100 \mathrm{ppb}$. This sensitivity, however, did not prove to be a problem because either the rhodamine concentrations were too low or there was not a coincident injection of tinopal while concentrations of rhodamine were high.

Tracers were usually injected into the glacier by pouring them into crevasses and occasionally into moulins. Crevasses probably drain most of the surface meltwater into the interior of the glacier (Schommer, 1977; Fountain, 1989). To avoid the problem of a tracer being trapped by a sealed crevasse, tracers were injected only into those crevasses in which water was heard running. Tracers also were injected into boreholes drilled to the bed of the glacier. To release the tracer at a specific level, an injector was constructed so that the caps of the container holding the tracer opened when a weighted messenger, dropped along the cable, hit the top of the injector. The volume of tracer injected was 0.07-1.0 l of concentrated rhodamine WT, and 1-3.7 l of tinopal CBS$\mathrm{X}$ of a saturated solution at $0^{\circ} \mathrm{C}$.

* The use of trade or product names is for identification purposes and does not constitute endorsement by the U.S. Geological Survey. 
TRACER RESULTS AND GENERAL FLOW PATTERNS

Forty-five tracer injections were made into South Cascade Glacier during the two field seasons, six in 1986 and 39 in 1987. Of this total, $36(80 \%)$ were detected, and the recovery fraction (detected volume divided by injected volume) ranged from 0.3 to 1.2 with a mean of about 0.6 . Tracers were detected in two of the three streams that drained the glacier. A consistent pattern emerged between the injection location and stream where the tracer emerged (Fig. 2); stream 2 drains most of the ablation zone on the east side of the glacier and stream 3 drains the accumulation zone, a smaller part of the upper ablation zone on the west side and a narrow strip in the lower ablation zone. Stream 4 drains a small part of the ablation zone along the western margin near the glacier terminus. Calculation of a water balance that compared water input (snowmelt, icemelt and precipitation) to measurements of stream discharge corroborated the areas of the glacial drainage basins and better defined the boundaries between them. These calculations (Fountain, in press a) showed that $30 \%$ of the glacier surface drained to stream 2, $69 \%$ of the surface drained to stream 3 and the remaining $1 \%$ drained to stream 4 . Attempts to measure the discharge of stream 4 were not very successful because of its unstable channel. Considering its small drainage area and poor measurements, it will not be considered further. The results of the tracer injections are divided into two groups according to the stream, and hence drainage basin, in which they were detected. Table 1 summarizes the results from stream 3 and Table 2 summarizes the results from stream 2.

The water divides of each basin, depicted in Figure 2, are surface divides. The subglacial divides, however, may be different. For example, a paired injection where one tracer was injected into a borehole and another tracer was simultaneously injected into a nearby crevasse (location A in Figure 2) indicated that the surface water reached stream 2 and the sub-surface water reached stream 3 . This is expected if the factors controling the position of the divides are different. On the surface, as pointed out by Stenborg (1973), crevasse orientation and surface slope control the water divides. There is little information about subglacial water divides. If the bed is covered with debris, as might be the case for much of South Cascade Glacier, then the position of water divides may coincide with the locations of bedrock protrusions from the debris. Another kind of subglacial divide can form along the margins of a subglacial conduit if the surrounding ice is in direct contact with bedrock. This is thought to be the case for the region under the narrow drainage strip in the lower ablation zone. Evidence for this situation was found on former subglacial beds (Walder and Hallet, 1979) and has been considered theoretically (Weertman, 1972).

Shreve (1972) predicted the position of subglacial divides based on the thickness and surface slope of the ice and slope of the bedrock surface, assuming that the pressure in the subglacial conduits is equal to the overburden pressure of the ice. Although this assumption may be valid for thick ice sheets on gently sloping bedrock (Röthlisberger, 1972; Shreve, 1985), it may not be valid for thin glaciers on steeply sloping bedrock, such as South
Cascade Glacier. Using Shreve's method, the predicted subglacial divides neither match the surface divides depicted in Figure 2 nor the subglacial divides from the paired surface-borehole injection. Most likely, the conduits in the lower part of the ablation zone of South Cascade Glacier are partly full most of the time, as indicated by comparing the rate of conduit closure from the overburden pressure of the ice to the rate of enlargement from viscously dissipated heat from the flowing water (Hooke, 1984).

The velocity and dispersion of tracers injected into the stream 2 basin differed from those of tracers injected into the stream 3 basin. The mean velocity, based on a straight-line distance from injection point to detection point divided by travel time, the time between injection and arrival of the peak concentration, is $0.07 \mathrm{~m} \mathrm{~s}^{-1}$ for tracers injected in the stream 2 basin and $0.14 \mathrm{~m} \mathrm{~s}^{-1}$ for the stream 3 basin. These velocity values are within the range of values for South Cascade Glacier determined by Krimmel and others (1973). The difference in dispersion can be seen by comparing typical concentration-time curves from each basin. The concentration-time curves from tracers injected in the stream 3 basin were sharply peaked (Fig. 3). In contrast, curves from the stream 2 basin were broadly dispersed, with many individual peaks of high tracer concentration (Fig. 3). These differences
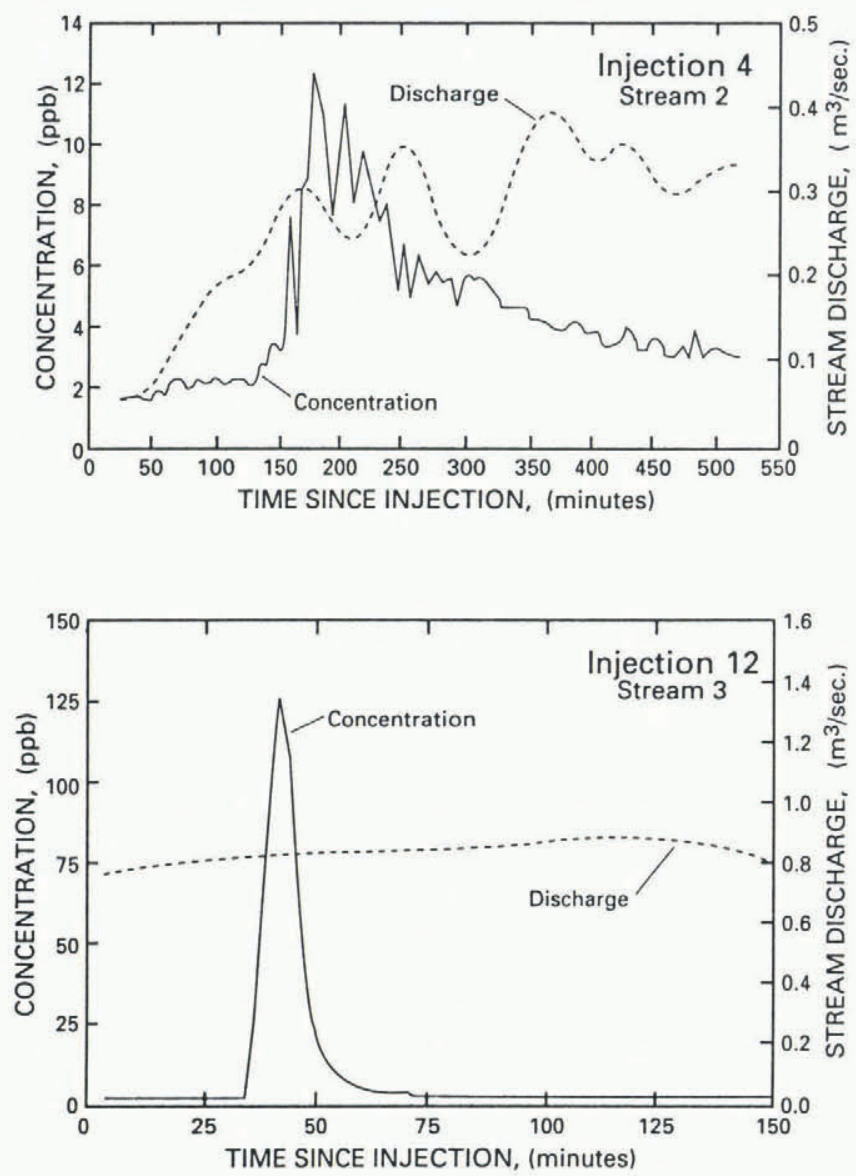

Fig. 3. Examples of concentration-time curves considered typical for injections into the stream 2 and stream 3 basins. The stream 2 injection was made adjacent to the $1700 \mathrm{~m}$ contour in Figure 2, and the stream 3 injection was made at the $1775 \mathrm{~m}$ contour. 
persisted despite changes in water discharge and differences in distance traveled.

The sharply peaked concentration-time curves of stream 3 suggest a channelized flow system, because the water is routed with relatively little dispersion. The existence of a narrow drainage strip on the glacier surface in the lower ablation zone (Fig. 2) may indicate the presence of a single conduit in that region and the drainage strip was a surface indication of its existence. Although conduits are thought to exist in other glaciers

Table 1. Results of tracer injections in the stream 3 basin. Inj is the injection number; a superscript indicates that the location is the same as a previous injection. Date is the day and month of injection: $\mathcal{F}, \mathrm{Fuly;}$ A, August; and S, September. Type indicates kind of injection: $S$, surface injection; $c$, crevasse; $m$, moulin; $B$, borehole injection; $i$, injector was used; and $p$, tracer was poured from the surface. Tracer is the variety of tracer used, $R$ denotes rhodamine $W T$ and $T$ denotes tinopal CBS-X. Dist is the straight-line distance between the injection and detection. Veloc is the velocity calculated from the distance and travel time. $Q$ is the stream discharge averaged for the time between injection and peak concentration, and - is no data

\begin{tabular}{cccccc}
\hline Inj Date & Tocal \\
daylight time & Type & Tracer & Dist & $\begin{array}{c}\text { Travel } \\
\text { time }\end{array}$ & Velocity \\
& & $\mathrm{m}$ & $\min$ & $\mathrm{ms}^{-1}$ & $\mathrm{~m}^{3} \mathrm{~s}^{-1}$ \\
\hline
\end{tabular}

\begin{tabular}{|c|c|c|c|c|c|c|c|c|}
\hline 5 & $20 \mathrm{~J}$ & 1046 & $\mathrm{Sm}$ & $\mathrm{R}$ & 485 & 54 & 0.15 & 0.72 \\
\hline 6 & $20 \mathrm{~J}$ & 1520 & $\mathrm{Bp}$ & $\mathrm{R}$ & 660 & 100 & 0.11 & 0.81 \\
\hline 7 & $20 \mathrm{~J}$ & 1130 & $\mathrm{Sc}$ & $\mathrm{R}$ & 785 & - & - & - \\
\hline $8^{5}$ & $23 \mathrm{~J}$ & 1135 & $\mathrm{Sc}$ & $\mathrm{T}$ & 485 & 35 & 0.23 & 0.50 \\
\hline $9^{7}$ & $23 \mathrm{~J}$ & 1240 & $\mathrm{Sc}$ & $\mathrm{T}$ & 785 & 60 & 0.22 & 0.59 \\
\hline 11 & $24 \mathrm{~J}$ & 1315 & $\mathrm{Sm}$ & $\mathrm{T}$ & 485 & - & - & - \\
\hline $12^{9}$ & $18 \mathrm{~A}$ & 1552 & $\mathrm{Sc}$ & $\mathrm{T}$ & 785 & 41 & 0.32 & 0.80 \\
\hline 13 & $18 \mathrm{~A}$ & 1540 & $\mathrm{Sc}$ & $\mathrm{R}$ & 835 & 140 & 0.10 & 0.82 \\
\hline 14 & $19 \mathrm{~A}$ & 1155 & $\mathrm{Sc}$ & $\mathrm{T}$ & 910 & - & - & - \\
\hline 15 & $19 \mathrm{~A}$ & 1135 & $\mathrm{Sc}$ & $\mathrm{R}$ & 1065 & - & - & - \\
\hline 18 & $20 \mathrm{~A}$ & 1115 & $\mathrm{Sc}$ & $\mathrm{R}$ & 1160 & 167 & 0.12 & 0.43 \\
\hline $20^{5}$ & $20 \mathrm{~A}$ & 1605 & $\mathrm{Sc}$ & $\mathrm{T}$ & 485 & 45 & 0.18 & 0.61 \\
\hline 22 & $21 \mathrm{~A}$ & 0850 & $\mathrm{Sc}$ & $\mathrm{R}$ & 1355 & 485 & 0.047 & - \\
\hline $23^{5}$ & $21 \mathrm{~A}$ & 0955 & $\mathrm{Sc}$ & $\mathrm{T}$ & 485 & 115 & 0.070 & - \\
\hline $25^{5}$ & $21 \mathrm{~A}$ & 1540 & $\mathrm{Sc}$ & $\mathrm{T}$ & 485 & 40 & 0.20 & - \\
\hline 26 & $22 \mathrm{~A}$ & 1530 & $\mathrm{Bi}$ & $\mathrm{R}$ & 1160 & 165 & 0.12 & - \\
\hline $27^{18}$ & $22 \mathrm{~A}$ & 1535 & $\mathrm{Sc}$ & $\mathrm{T}$ & 1160 & 185 & 0.10 & - \\
\hline 28 & $25 \mathrm{~A}$ & 1535 & $\mathrm{Bp}$ & $\mathrm{T}$ & 510 & - & - & - \\
\hline 30 & $26 \mathrm{~A}$ & 1534 & $\mathrm{Bi}$ & $\mathrm{R}$ & 1335 & - & - & - \\
\hline 31 & $18 \mathrm{~S}$ & 1325 & $\mathrm{Bi}$ & $\mathrm{R}$ & 1185 & 295 & 0.067 & 0.17 \\
\hline $32^{5}$ & $19 S$ & 1310 & $\mathrm{Sc}$ & $\mathrm{T}$ & 485 & 52 & 0.16 & 0.18 \\
\hline $33^{5}$ & $19 \mathrm{~S}$ & 1610 & $\mathrm{Sc}$ & $\mathrm{T}$ & 485 & 44 & 0.18 & 0.24 \\
\hline $34^{13}$ & $20 \mathrm{~S}$ & 1240 & $\mathrm{Sc}$ & $\mathrm{T}$ & 835 & 97 & 0.14 & 0.29 \\
\hline $35^{6}$ & $20 \mathrm{~S}$ & 1615 & $\mathrm{Bp}$ & $\mathrm{T}$ & 660 & 50 & 0.22 & 0.41 \\
\hline 36 & $21 \mathrm{~S}$ & 1020 & $\mathrm{Sm}$ & $\mathrm{R}$ & 3335 & 475 & 0.12 & 0.56 \\
\hline $37^{22}$ & $21 \mathrm{~S}$ & 1125 & $\mathrm{Sc}$ & $\mathrm{T}$ & 1355 & - & - & - \\
\hline $38^{22}$ & $22 \mathrm{~S}$ & 1055 & $\mathrm{Sc}$ & $\mathrm{R}$ & 1355 & - & - & - \\
\hline 39 & $29 \mathrm{~S}$ & 1750 & $\mathrm{Sc}$ & $\mathrm{R}$ & 2160 & - & - & - \\
\hline
\end{tabular}

1986

\begin{tabular}{rllllrrrr}
1 & $13 \mathrm{~A}$ & 1700 & $\mathrm{Bi}$ & $\mathrm{R}$ & 962 & - & - & - \\
3 & $16 \mathrm{~A}$ & 1214 & $\mathrm{Sc}$ & $\mathrm{R}$ & 429 & 105 & 0.068 & - \\
5 & $21 \mathrm{~S}$ & 1215 & $\mathrm{Bi}$ & $\mathrm{R}$ & 1034 & 1524 & 0.011 & - \\
\hline
\end{tabular}


Table 2. Results of tracer injections in the stream 2 basin. Inj is the injection number; a superscript indicates that the location is the same as a previous injection. Date is the day and month of injection: $\mathcal{7}$, July; A, August; S, September. Type indicates kind of injection: $S$, surface injection; $c$, crevasse; $m$, moulin; $B$, borehole injection; $i$, injector was used; and $p$, tracer was poured from the surface. Tracer is the variety of tracer used, $R$ denotes rhodamine $W T$ and $T$ denotes tinopal CBS-X. Dist is the straight-line distance between the injection and detection. Veloc is the velocity calculated from the distance and travel time. $Q$ is the stream discharge averaged for the time between injection and peak concentration, and - is no data

\begin{tabular}{|c|c|c|c|c|c|c|c|c|}
\hline Inj & Date & $\begin{array}{c}\text { Local } \\
\text { daylight time }\end{array}$ & Type & Tracer & Dist & $\begin{array}{c}\text { Travel } \\
\text { time }\end{array}$ & Velocity & $Q$ \\
\hline & & & & & $\mathrm{m}$ & $\min$ & $\mathrm{ms}^{-1}$ & $\mathrm{~m}^{3} \mathrm{~s}^{-1}$ \\
\hline
\end{tabular}

1987

$\begin{array}{lllllrrrr}1 & 18 \mathrm{~J} & 1550 & \mathrm{Sm} & \mathrm{R} & 470 & 104 & 0.075 & 0.54 \\ 2 & 19 \mathrm{~J} & 1242 & \mathrm{Sc} & \mathrm{T} & 465 & 148 & 0.052 & 0.30 \\ 3 & 19 \mathrm{~J} & 1235 & \mathrm{Sm} & \mathrm{R} & 420 & 312 & 0.022 & 0.28 \\ 4^{3} & 20 \mathrm{~J} & 1050 & \mathrm{Sm} & \mathrm{T} & 420 & 175 & 0.040 & 0.13 \\ 10 & 23 \mathrm{~J} & 1530 & \mathrm{Sc} & \mathrm{T} & 440 & 163 & 0.045 & 1.02 \\ 16 & 19 \mathrm{~A} & 1430 & \mathrm{Sm} & \mathrm{T} & 920 & 100 & 0.15 & 0.05 \\ 17 & 19 \mathrm{~A} & 1405 & \mathrm{Sm} & \mathrm{R} & 1055 & 280 & 0.063 & 0.03 \\ 19 & 20 \mathrm{~A} & 1120 & \mathrm{Sm} & \mathrm{T} & 510 & 300 & 0.028 & 0.09 \\ 21^{19} & 20 \mathrm{~A} & 1615 & \mathrm{Sm} & \mathrm{R} & 510 & 125 & 0.068 & 0.07 \\ 24^{1} & 21 \mathrm{~A} & 1530 & \mathrm{Sm} & \mathrm{T} & 470 & 90 & 0.087 & - \\ 29 & 26 \mathrm{~A} & 1335 & \mathrm{Sc} & \mathrm{T} & 1195 & 290 & 0.069 & - \\ 31 & 18 \mathrm{~S} & 1325 & & \mathrm{~B} & \mathrm{R} & 1185 & 295 & 0.067\end{array}$

1986

\begin{tabular}{lllllllll}
2 & $15 \mathrm{~A}$ & 1056 & $\mathrm{Sm}$ & $\mathrm{R}$ & 671 & 125 & 0.090 & - \\
4 & $16 \mathrm{~A}$ & 1540 & $\mathrm{Ss}$ & $\mathrm{R}$ & 545 & 100 & 0.091 & - \\
7 & $22 \mathrm{~S}$ & 1505 & $\mathrm{Sm}$ & $\mathrm{R}$ & 814 & 325 & 0.042 & - \\
\hline
\end{tabular}

that show no drainage strip (Seaberg and others, 1988), the situation at South Cascade Glacier may result from the fortuitous alignment of crevasses parallel to the conduit.

Up-glacier from the narrow drainage strip the drainage basin widens, yet the shape of the concentration-time curves of surface injections maintain a single peak with little dispersion. This implies that surface water is routed through a channelized network that efficiently funnels water from branches that converge to the main conduit (arborescent) under the narrow drainage strip. The small secondary peaks in the concentration-time curves indicate that secondary flow paths exist but do not route much of the water. One exception is injection 36 (Fig. 4), made close to the head of the glacier, indicates that channelized flow paths run the length of the glacier. The secondary peaks, associated with injection 36, indicate slower alternative flow paths or flushing of reservoirs in the upper regions of the glacier.

In stream 2, the more disperse concentration-time curves indicate a distributed flow system composed of multiple flow paths.
To detect differences in near-surface and subglacial flow processes, simultaneous injections were made in crevasses and nearby boreholes. One difference between surface and borehole injections is that they did not always

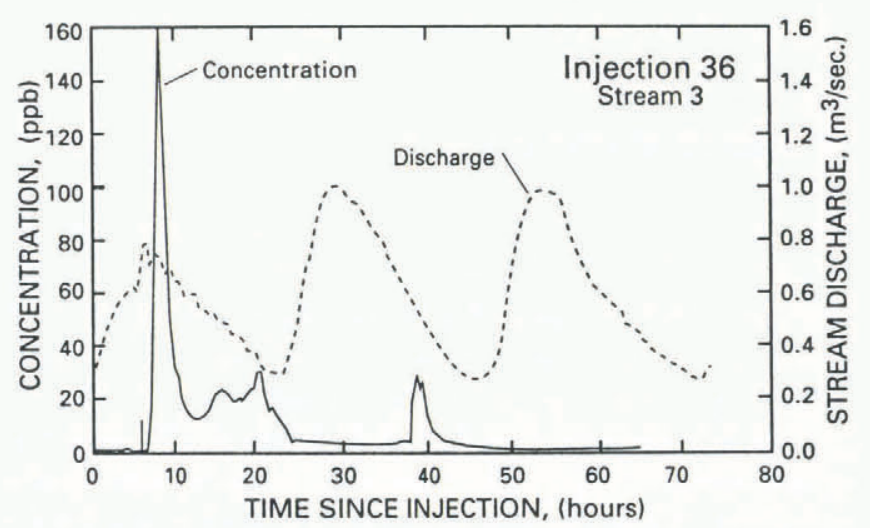

Fig. 4. Concentration-time curve for injection 36 made close to the head of the glacier. 
appear in the same stream, indicating that the location of surface and sub-surface water divides is not the same as previously discussed. Another difference between the surface and borehole injections is the difference in their dispersion. Concentration-time curves from borehole injections exhibit much greater dispersion than surface injections, more typical of results from the stream 2 basin rather than of the surface injections of the stream 3 basin. This implies two parallel flow systems in the upper part of the ablation zone consisting of a channelized englacial system that routes much of the surface water directly to a subglacial conduit and a distributed-flow subglacial system. The comparison of solute load and water discharge in stream 3 provides independent evidence for a dual flow system (Fountain, in press b). The solute load is relatively constant despite a widely varying water discharge and implies a solute source not affected by diurnal melt processes. A dual flow system can explain this result.

Some of the tracer from borehole injection 31 (Fig. 2) also appeared in stream 2 and represents the only occasion when a tracer appeared in both streams from the same injection. It is not clear how the tracer from the location of injection 31 traveled to stream 2, as tracers from borehole injections 26 and 30 did not. The measured concentrations for injections 26 and 30 were low and perhaps were undetectable in stream 2.

Borehole injections are difficult to interpret without additional information. The borehole may intersect englacial and subglacial flow systems and provide an artificial connection between them. This phenomenon has been observed at Columbia Glacier (personal communication from N. Humphrey, 1988) and similar upward flow in boreholes is inferred to occur on Storglaciären (Hooke and others, 1988). If a tracer was injected at the bottom of a borehole, it might travel up the borehole to an englacial connection, although one would be inclined to interpret the results in terms of subglacial flow. Conversely, it is possible that an injection at the bed may be transported into the bed directly without delay. Tracers poured into a borehole from the top are particularly poor indicators of subglacial flow because the tracer must first travel through the full water height to reach the bed. Unless the direction and speed of water flow in a borehole are known, conclusions about the subglacial hydraulics based on tracer dispersion and travel time from injections in boreholes must be regarded with caution.

\section{HYDRAULIC CONDITION}

The hydraulic condition of conduit flow, either partly filled conduit or pressurized, can be examined by using two independent measures of the flow: travel time of injected tracers (water velocity) and water discharge. Knowing that the mean velocity of the water, $V=L / T$, where $L$ is the path length and $T$ is travel time and the water discharge $Q=A V$, where $A$ is the average crosssectional area of the flow, then the travel time of a tracer can be expressed as

$$
T=\frac{A L}{Q} .
$$

Taking logarithms and differentiating with respect to $Q$ yields

$$
\frac{\partial \log (T)}{\partial \log (Q)}=\frac{\partial[\log (A)+\log (L)-\log (Q)]}{\partial \log (Q)} .
$$

If the tracers are injected at the same location, the path length, $L$, is constant and the equation reduces to

$$
\frac{\partial \log (T)}{\partial \log (Q)}=\frac{\partial \log (A)}{\partial \log (Q)}-1
$$

If the water flow is pressurized, the cross-sectional flow area does not change and the derivative is equal to -1 , indicating, simply, that travel time is inversely related to discharge.

For partly filled conduits, the slope will be less negative and is related to the geometry of the conduit cross-section. I assume that the relation between crosssectional area and discharge is adequately described by Manning's equation (Roberson and Crowe, 1985)

$$
Q=\frac{A R^{\frac{2}{3}} S^{\frac{1}{2}}}{n}
$$

where $R$ is the hydraulic radius, $S$ is slope of the water surface for steady, uniform flow and $n$ is the Manning's roughness coefficient. $\mathrm{Re}$-arranging Equation (4) to solve for the cross-sectional area, $A$, and substituting into Equation (3) yields

$$
\frac{\partial \log (T)}{\partial \log (Q)}=\frac{\partial}{\partial \log (Q)}\left[\log \left(\frac{n}{S^{\frac{1}{2}}}\right)-\frac{2}{3} \log (R)\right] .
$$

The water-surface slope is assumed to approximate the bed slope. Although roughness varies with flow depth in a conduit, its rate of change is small compared to the rate of change of hydraulic radius (Chow, 1959) and may also be assumed constant. With these two assumptions, Equation (5) reduces to

$$
\frac{\partial \log (T)}{\partial \log (Q)} \approx-\frac{2}{3} \frac{\partial \log (R)}{\partial \log (Q)} .
$$

The change in travel time of the tracer, as a function of a change in water discharge, is related to the change in hydraulic radius.

To assess the slope of $\log T$ versus $\log Q$ for various hypothetical cross-sectional shapes, the travel time $T$ was calculated from a given discharge and roughness by Equation (4) using a constant path length. The results (Fig. 5) show that the slopes for a partly filled conduit vary from -0.40 for a rectangle with a width-to-height ratio of $50: 1$ to a slope of -0.02 for a ratio of $1: 50$. The slope for a circular cross-section closely approximates a square $(1: 1)$ and a half-circle closely approximates a rectangle of a ratio of $3: 1$.

From these simple relations, it might seem that careful measurements could distinguish among partly filled and pressurized conduits, and with careful field procedures determine some features of the flow cross-section geometry. However, the conduit may be pressurized for a distance and flow partly filled for the remainder. The effect of this situation was calculated by assuming a conduit of two different radii. In the smaller conduit, the water flow is pressurized and the larger conduit is about half full. The slope is then calculated by averaging the 


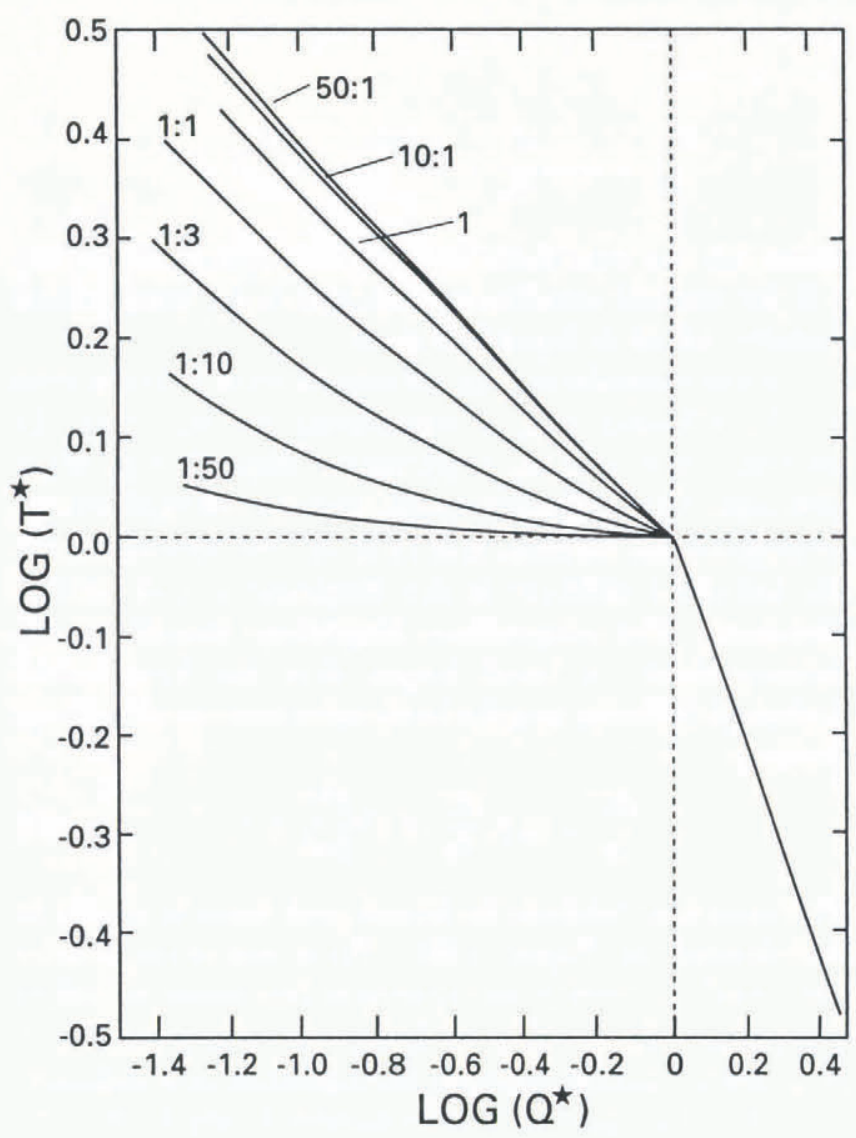

Fig. 5. Calculated relation between the logarithm of tracer travel time and water discharge for different rectangular cross-sections with various width-to-depth ratios. $\mathcal{T}^{*}$ is dimensionless travel time (travel time divided by the time for a conduit full of water but not pressurized above atmospheric pressure) and $Q^{*}$ is dimensionless discharge (discharge divided by the discharge required to fill the conduit). The dashed lines indicate the travel time and discharge for a filled conduit but not pressurized above atmospheric pressure. slope of the partly filled and pressurized parts, each weighted by their fraction of total length. Although this conceptualization is not a truly accurate description of open/closed conduit conditions, the essence of the predicted change in behavior is probably correct. The change in slope for different fractions of a partly filled conduit is shown in Table 3 .

The application of this method requires a data set composed of multiple injections at the same location over a relatively short time period (a few days). The time constraint is necessary because the geometry of the flow system changes over time. For the three periods of injections at South Cascade Glacier, the geometry is assumed constant during each period. Multiple injections were made at South Cascade Glacier during the 1987 field season but not at the frequency necessary at a single

Table 3. The calculated slope of $\log (\tau) / \log (Q)$ for different length fractions of a partly filled conduit with a circular cross-section

Fraction of path length flowing partly filled $\mathrm{d} \log (\tau) / \mathrm{d} \log (Q)$

Table 4. The slope of $\partial \log (\tau) / \partial \log (Q)$ for the stream 3 basin at South Cascade Glacier and other flow systems for comparison. $Q$ is the average stream discharge for the period during the injections. The inferred flow condition is designated as of for a partly filled channel flow and $\bullet$ for pressurized. The two symbols together indicate that some fraction of the flow path is pressurized and the remainder is partly filled. $Q$ is the mean stream discharge during the injection travel time. The data from Peyto Glacier are found in Collins (1982), from Hintereisferner in Behrens and others (1975) and from the Maligne Karst in Smart (1988)

\begin{tabular}{|c|c|c|c|c|c|}
\hline Study site & Period & $\begin{array}{l}\text { Number of } \\
\text { injections }\end{array}$ & $\frac{\partial \log (\tau)}{\partial \log (Q)}$ & $\begin{array}{c}Q \\
\mathrm{~m}^{3} \mathrm{~s}^{-1}\end{array}$ & $\begin{array}{c}\text { Flow } \\
\text { condition }\end{array}$ \\
\hline $\begin{array}{l}\text { South Cascade } \\
\text { Glacier }\end{array}$ & $\begin{array}{l}20-23 \text { Jul } \\
19-20 \text { Aug } \\
19-20 \text { Sep }\end{array}$ & $\begin{array}{l}3 \\
2 \\
3\end{array}$ & $\begin{array}{r}2.28 \\
-0.70 \\
-0.54\end{array}$ & $\begin{array}{l}0.65 \\
0.66 \\
0.28\end{array}$ & $\begin{array}{l}\bullet \\
0 / \bullet \\
0 / \bullet\end{array}$ \\
\hline Peyto Glacier & $\begin{array}{l}27-28 \mathrm{Jul} \\
22-23 \text { Aug }\end{array}$ & $\begin{array}{l}5 \\
6\end{array}$ & $\begin{array}{l}-0.41 \\
-1.02\end{array}$ & $\begin{array}{r}7.3 \\
15.9\end{array}$ & $\begin{array}{l}0 \\
\bullet\end{array}$ \\
\hline Hintereisferner & 24-25 Jul & 14 & 1.45 & 6.8 & $\bullet$ \\
\hline Maligne Karst & Several years & 6 & -0.86 & $2-40.0$ & o/• \\
\hline
\end{tabular}


location for this analysis. An attempt to overcome this problem was made by selecting injections relatively close to each other and by scaling the travel time by the ratio of the mean distance to the actual distance. This solution is justified by the linear relation between travel time and distance, although there is deviation from the linear relation that certainly affects the result. The results are tabulated in Table 4. The slopes of $\partial \log (T) / \partial \log (Q)$ in Table 4 are based on a least-squares fit to the data.

For South Cascade Glacier, the positive slope in July indicates that the travel time increases with increasing discharge. Once a conduit becomes pressurized, water may back up the passages that route water from the surface to the conduit. A tracer injected at the glacier surface must move through the column of water to the conduit. As the pressure in the conduit increases, the water level rises in the connecting passage and the tracer requires a longer time to reach the conduit. The increasing travel time with discharge will cause a positive slope.

For August and September the slope is negative but more negative than -0.4 , suggesting that the flow path is pressurized for only part of the total distance (Table 3). The discharges for the two periods in July and August are similar, while the slopes are different, suggesting that the flow passage enlarged during the time between the July and August injections. In September, the water discharge decreased and the slope is less negative, indicating that less of the flow path is pressurized compared to August.

Tracers were injected into the same location on Peyto Glacier during two different periods (Collins, 1982). The slope of the logarithm of travel time with respect to the logarithm of discharge for the July data is -0.41 , suggesting that most of the flow path was flowing partly filled. The water discharge in August was more than twice that in July, and a slope of -1.00 suggests that the flow path was pressurized. The positive slope for the data from Hintereisferner (Behrens and others, 1975) suggests that the flow path was pressurized and the water had backed up the moulin.

Data from the Maligne Karst system (Smart, 1988) were included in this analysis because flow in a karst system is analogous to flow in a glacier. Although the data were collected over a period of years, the geometry of the subterranean flow system does not change quickly like that for a glacial system. The results indicate a flow system with pressurized and partly filled flow conditions. Considering the range of water discharges, it seems likely that a variety of conditions should occur.

\section{TRACER DISPERSION IN CHANNELIZED FLOW}

The concentration of a tracer in a flowing system can be described mathematically as (Fischer and others, 1979)

$$
\frac{\partial C}{\partial t}+\mathbf{u} \cdot \nabla C=D \nabla^{2} C+I
$$

where $C$ is the tracer concentration, $\mathbf{u}$ is the velocity vector for uniform flow, $D$ is the isotropic diffusion coefficient and $I$ is the summation of source-sink terms. For application to uniform flow in subglacial conduits, and considering that little is known about the channel geometry and path, the general equation is reduced to two dimensions

$$
\frac{\partial C}{\partial t}+u(z) \frac{\partial C}{\partial x}=D\left[\frac{\partial^{2} C}{\partial x^{2}}+\frac{\partial^{2} C}{\partial z^{2}}\right]+I
$$

where $x$ is the coordinate in the downslope direction and $z$ is the vertical coordinate, and $u(z)$ is the longitudinal velocity, which is dependent on $z$.

In this formulation, the advection term (second term on the lefthand side) is responsible for not only the advection but also the longitudinal dispersion in the $x$ direction. The dispersion results from the vertical change in longitudinal velocity, $u(z)$ (Fig. 6). The second term is the turbulent diffusion in the longitudinal and vertical directions. The longitudinal dispersion, caused by the velocity shear, is much larger than the longitudinal turbulent diffusion and the latter term may be eliminated yielding

$$
\frac{\partial C}{\partial t}+u(z) \frac{\partial C}{\partial x}=D \frac{\partial^{2} C}{\partial z^{2}}+I .
$$

This equation (without the source-sink term) is similar to that derived by Taylor (1953). From this point, Taylor proceeded to develop an expression that could be solved analytically. In so doing, he formed a "virtual coefficient of diffusion" that combines both dispersion and diffusion. The resulting equation is the commonly used advectiondiffusion equation. However, by keeping these terms separate, and exploiting our understanding of flow in channels, the cross-sectional geometry of flow can be estimated.

The velocity structure for clean, turbulent flow in open channels is approximated by a logarithmicparabolic profile (Rattray and Mitsuda, 1974)

$$
\begin{array}{ll}
u=\frac{u_{*}}{k} \ln \frac{\epsilon}{\epsilon_{\mathrm{o}}} & \epsilon \leq 0.2 \\
u=\frac{u_{*}}{k}\left\{\ln \frac{0.2}{\epsilon_{\mathrm{o}}}+6.24\left(\epsilon-0.5 \epsilon^{2}-0.18\right)\right\} & \epsilon \geq 0.2
\end{array}
$$

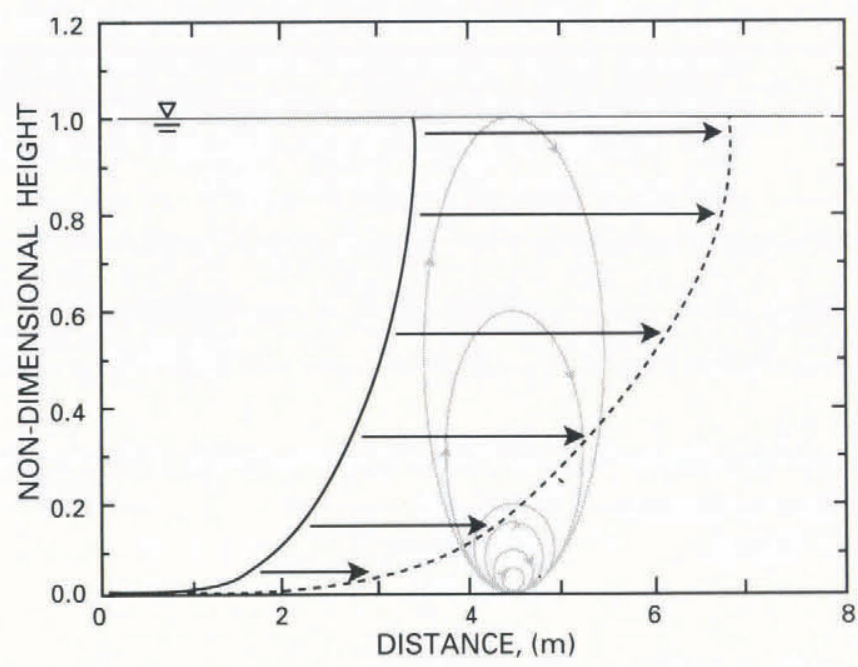

Fig. 6. Longitudinal dispersion of a tracer by advection. The heavy line is the trace front 1 s after an injection and the dashed line is the advection after $2 s$. Note that the nearsurface water is advected further downstream than that at the bed. Turbulent diffusion (light lines) mixes the tracer vertically. 
where $u$ is the velocity, $u^{*}$ is the shear velocity, and equal to $(g H S)^{\frac{1}{2}}$, where $g$ is gravity, $H$ is flow depth and $S$ is slope; $k$ is von Karman's constant and equals $0.4 . \epsilon$ is the non-dimensional depth (depth divided by total flow depth), and $\epsilon_{\mathrm{o}}$ is the non-dimensional roughness height (roughness height divided by the total flow depth). The roughness height is the length scale of the bed roughness divided by 30 , based on the assumption of hydrodynamically rough flow (Nikuradse (1933), summarized by Roberson and Crowe, 1985)). This approximation for the vertical profile of velocity is that for a channel much wider than deep, flowing at atmospheric pressure. As will be shown later, the channels probably are wide relative to their depth and with a width to depth ratio greater than $10: 1$; the bed shear stress accounts for more than $90 \%$ of the total shear stress in such channels (Shimizu, 1989). Other common formulations of the velocity profile could be used, such as a fully logarithmic profile, but these would not affect either the advection or the mixing calculation appreciably. The channels are also probably flowing partly full (atmospheric pressure) based on comparison of channel enlargement and closure rates (Hooke, 1984) for the situation at South Cascade Glacier.

The first term on the righthand side in Equation (7) is the turbulent diffusion in the vertical dimension. The magnitude of $D$ is assumed to be equal to the eddy diffusivity using the common assumption that the mixing coefficients for momentum and mass are equal in turbulent flows. From the definition of shear stress in a viscous fluid and the velocity profile given by Equations (8), the eddy viscosity can be calculated as

$$
\begin{array}{rlrl}
D & =k u_{*} z(1-\epsilon) & \epsilon & \leq 0.2 \\
D & =\frac{k u_{*} H}{6.24} & \epsilon>0.2
\end{array}
$$

where $z$ is vertical height in the flow and $H$ is the total flow depth.

Tracer may flow through porous gravel that may reside on the bottom of the subglacial conduit. The pore velocity of flow in the gravel is equal to Darcy's law divided by the porosity

$$
u_{\text {bed }}=\frac{K S}{\phi}
$$

where $K$ is the hydraulic conductivity, $S$ is the bed slope, an approximation to the slope of the water surface, and $\phi$ is the porosity. The depth of the gravel bed must also be specified. Diffusion of the tracer in the porous bed is assumed to scale with the pore-water velocity and pore diameter (Scheidegger, 1974, p. 306). Equation (7), using Equations (8), (9) and (10), was numerically solved by a finite-difference scheme.

\section{APPLICATION TO SOUTH GASCADE GLACIER}

The advection-dispersion model, without source-sink terms, was used only to interpret tracer injections in the stream 3 basin where a channel-flow system appears to exist. Although nine parameters can be adjusted, five of those dealing with the channel bed (roughness, thickness, permeability, porosity and pore diameter) were kept constant for all calculations. The values for some of these parameters were based on limited observations of the streams flowing from the glacier; bottom roughness $0.01 \mathrm{~m}$, bed thickness $0.05 \mathrm{~m}$; and tabulated values of porosity for a gravel, 0.4 , and hydraulic conductivity, $0.1 \mathrm{~m} \mathrm{~s}^{-1}$ (Freeze and Cherry, 1979). The fifth parameter, bed-pore diameter, was assumed to be $10^{-3} \mathrm{~m}$. Of the remaining four parameters, bed slope was estimated from a map of the basal topography (Hodge, 1979); unfortunately, the injected mass of tracer is not well known so the initial concentration was also adjusted within reasonable limits; water depth, sinuosity (path length divided by the length of a straight line between the location of injection and detection) were adjusted to match the observed data.

The correlation between calculated results and measured data was not very good; the falling limb of the calculated concentration-time curve decreased much too rapidly. This indicated that the advective dispersion and turbulent diffusion accounted for a small part of the total dispersion and that other dispersive processes exist. Such processes may include eddies (personal communication from J. Nelson, 1989), exchange with dead-water zones along the conduit margin (Bencala and Walters, 1983) and exchange with the porous bed. These processes failed to reconcile the empirical and numerical results when they were continuously distributed along the channel or when placed in discrete locations. Rather, the dispersion seemed independent of distance upstream, indicating a process in the flow path between the glacier surface and the subglacial channel rather than in the channel itself.

The tracers injected into the glacier may not reach the subglacial channel directly, as implicitly assumed. Holmlund (1988) showed for moulins that a series of englacial plunge pools existed along the flow path from the surface to the bed. If we conjecture that similar plunge pools exist in the flow path between crevasses and subglacial conduits, then the tracer would have been first routed through a pool before entering the channel. Mixing in a pool is approximated as a linear reservoir

$$
\frac{\partial C_{\mathrm{p}}}{\partial t}=\frac{q}{v}\left(C_{\mathrm{i}}-C_{\mathrm{p}}\right)
$$

where $C_{\mathrm{p}}$ is the concentration in the pool, $q$ is the water flux into and out of the pool, $v$ is the pool volume and $C_{\mathrm{i}}$ is the tracer concentration in the water flowing into the pool.

The value of $q$ was estimated from the mean daily melting rate of $0.037 \mathrm{~m} \mathrm{~d}^{-1}$, estimated width between crevasses of $2 \mathrm{~m}$ (the region is highly crevassed) and crevasse length of $20 \mathrm{~m}$, yielding a surface input of about $1.7 \times 10^{-5} \mathrm{~m}^{3} \mathrm{~s}^{-1}$. The pool volume was then varied to match the falling limb of the calculated curve to the data. The initial concentration of the pool was determined from the volume of tracer divided by the volume of the pool.

Inclusion of an instantaneously mixed pool (Equation (11)) to the advection-dispersion model (Equation (7)) significantly improved the match between calculated and measured concentrations. In so doing, four parameters (pool volume, tracer mass, water depth and sinuosity), rather than three, were adjusted to fit the calculations to the measurements. The water depth was weakly constrained by the magnitude of the measured discharge 
in that the water depth had increased with increasing discharge. The conduit may change cross-sectional area over time and therefore the stage-discharge relation was not kept constant between injection periods. Although there were no explicit constraints on the sinuosity, an attempt was made to keep the values in each injection period within a small range. Only those injections in which discharge measurements were available were fitted. The correlation between the calculated and measured concentration-time curves is very good; some examples are shown in Figure 7 and the parameters are summarized in Table 5 . Included in Table 5 is the width of the flow cross-section, which was calculated from measured discharge, estimated flow depth and calculated flow velocity. Injection 36 was made near the head of the glacier and exhibited multiple concentration peaks (Fig. 4 ), and the values in Table 5 are for the first peak.

If the flow is pressurized in July, as indicated by the results on flow condition (Table 4), then the flow depth is doubled and the flow width is halved. If this is true, then the conduits enlarged significantly during the 3 week interval between the July and August injection periods.
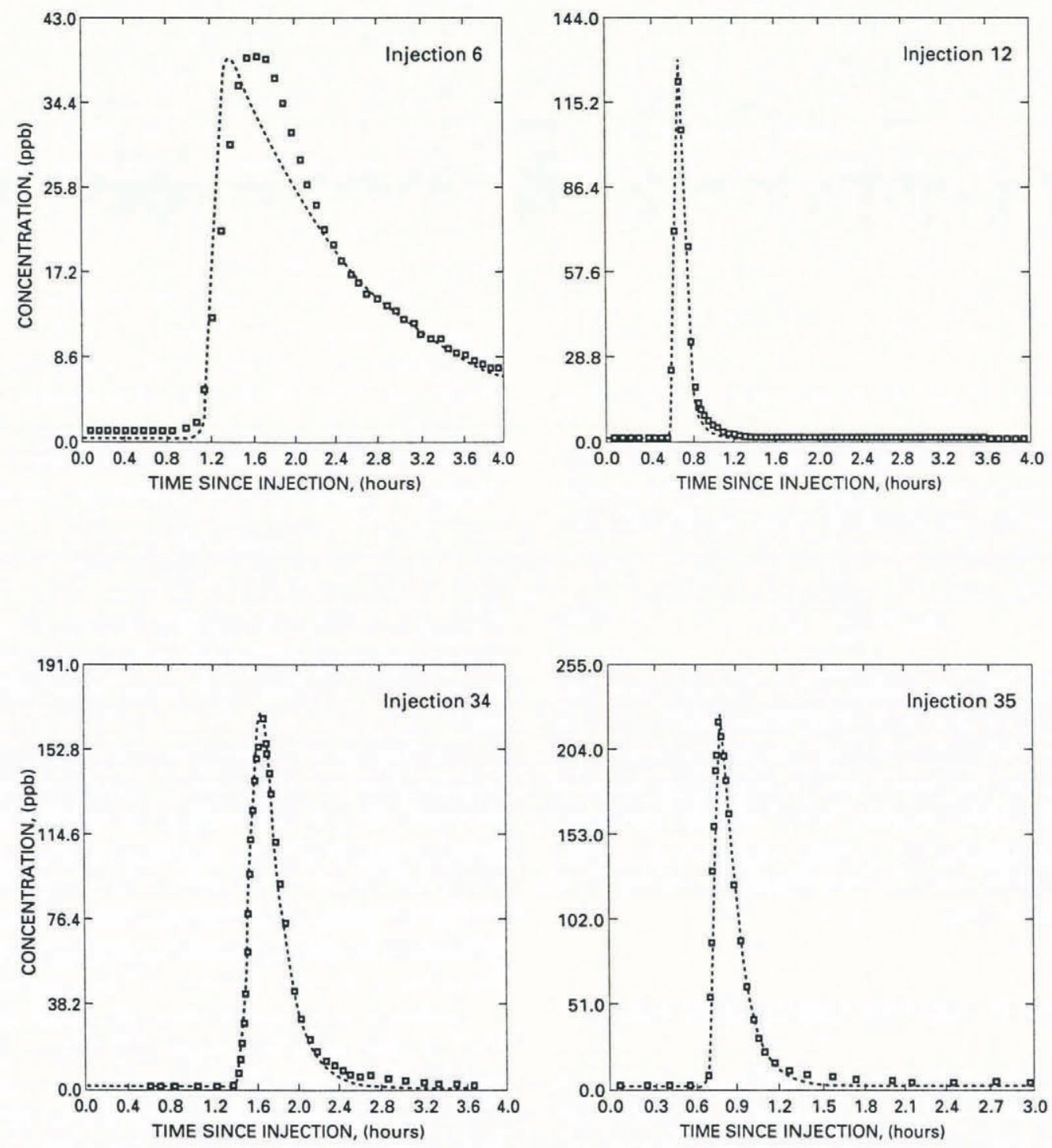

Fig. 7. Examples of typical results after fitting the advection-diffusion equation to empirical data. The squares are measured data and the dashed line is the fitted equation. Injection 6 is included to illustrate what is considered a poor fit.
The water flow during the interval had larger discharges for longer periods than previous times, resulting in accelerated conduit enlargement, a result of the viscous dissipation of turbulent energy into heat (Röthlisberger, 1972). There is no indication that either the sinuosity or flow width changed between injection periods of August and September. The estimated englacial pool volumes did not significantly change during the season.

The estimated sinuosity is much larger than reported for natural rivers, which rarely exceed a sinuosity of 2 (Schumm, 1977). Former subglacial channels, as revealed by patterns of subglacial precipitate (Walder and Hallet, 1979; Hallet and Anderson, 1980) and by eskers (Shreve, 1985), also do not exhibit highly sinuous paths. The unreasonable large estimates of sinuosity $(\lambda)$ in Table 5 result from having to delay the estimated arrival time of the tracer to match the measured arrival time. It is unlikely that the path length can be increased in any reasonable way so the drag must be larger than estimated.

The calculated flow velocity in the sinuous channels of Table 5 is about $1 \mathrm{~m} \mathrm{~s}^{-1}$, which compares favorably with velocities of $0.6-1.2 \mathrm{~m} \mathrm{~s}^{-1}$ measured in the proglacial 
Table 5. Flow characteristics derived from the advection-dispersion equation assuming partly filled flow conditions. $\lambda$ is the sinuosity

\begin{tabular}{|c|c|c|c|c|c|c|c|}
\hline No. & $\begin{array}{c}\text { Injection } \\
\text { date }\end{array}$ & $\begin{array}{l}\text { Measured } \\
\text { discharge } \\
\mathrm{m}^{3} \mathrm{~s}^{-1}\end{array}$ & $\begin{array}{c}\text { Flow } \\
\text { depth } \\
\text { m }\end{array}$ & $\lambda$ & $\begin{array}{l}\text { Flow } \\
\text { width } \\
\text { m }\end{array}$ & $\begin{array}{l}\begin{array}{l}\text { Pool } \\
\text { volume }\end{array} \\
\mathrm{m}^{3}\end{array}$ & Remarks \\
\hline 5 & $20 \mathrm{Jul}$ & 0.72 & 0.080 & 4.7 & 10.6 & 0.70 & \\
\hline 6 & $20 \mathrm{Jul}$ & 0.81 & 0.092 & 7.4 & 8.4 & 5.00 & Poor fit \\
\hline 8 & $23 \mathrm{Jul}$ & 0.50 & 0.070 & 3.6 & 7.9 & 0.25 & \\
\hline 9 & $23 \mathrm{Jul}$ & 0.59 & 0.075 & 5.3 & 6.3 & 1.15 & \\
\hline 12 & 18 Aug & 0.80 & 0.100 & 4.8 & 5.0 & 0.22 & \\
\hline 13 & 18 Aug & 0.82 & 0.110 & 8.8 & 5.9 & 10.00 & Poor fit \\
\hline 18 & 20 Aug & 0.43 & 0.060 & 5.8 & 10.1 & 5.20 & \\
\hline 20 & 20 Aug & 0.61 & 0.070 & 4.2 & 10.7 & 0.65 & \\
\hline 31 & $18 \mathrm{Sep}$ & 0.17 & 0.028 & 5.8 & 14.9 & 8.00 & Poor fit \\
\hline 32 & $19 \mathrm{Sep}$ & 0.18 & 0.031 & 3.2 & 11.6 & 0.50 & \\
\hline 33 & 19 Sep & 0.24 & 0.044 & 3.5 & 8.6 & 0.20 & \\
\hline 34 & $20 \mathrm{Sep}$ & 0.29 & 0.050 & 5.8 & 7.1 & 0.73 & \\
\hline 35 & $20 \mathrm{Sep}$ & 0.41 & 0.055 & 4.2 & 7.8 & 0.50 & \\
\hline 36 & $21 \mathrm{Sep}$ & 0.56 & 0.063 & 8.3 & 6.3 & 5.00 & \\
\hline
\end{tabular}

stream. In contrast, the inferred mean flow velocity through the glacier is $0.12 \mathrm{~m} \mathrm{~s}^{-1}$ and is typical of flow velocities inferred at other glaciers such as Midtdalsbreen (Willis and others, 1990) or Storglaciären (Seaberg and others, 1988). This order-of-magnitude difference between flow velocity in streams or conduits and inferred flow velocity through the glacier is striking and has been noted previously (Vivian, 1980). Therefore, other flow processes are present either within the conduit or in the englacial passage to the conduit that slow the passage of water.

Within the conduit, two processes have been considered that may slow the water: (1) a pool-and-riffle flow structure; and (2) increased roughness. Like subaerial streams, water in subglacial conduits may flow through a series of pools and riffles. The speed of water through the pools was calculated from the flux into and the crosssectional area of the pool. To account for the observed flow velocity, the cross-sectional area of the pool was estimated to be $100 \mathrm{~m}^{2}$ and comprised $90 \%$ of the flow distance. Clearly, these numbers are unreasonable and, although a pool-and-riffle structure may delay the flow somewhat, it cannot totally explain the delay.

In the numerical model, the roughness scale was a small fraction of the total water depth. However, the actual flow path may have roughness elements of approximately the same scale as the water depth. Mountain streams are often characterized by high roughness and it would not be unreasonable to expect subglacial conduits to differ greatly. Preliminary calculations of a velocity structure for such streams (personal communication from P. Wiberg, 1990; based on Wiberg and Smith, 1987) estimate a mean velocity about one-half that for the log-parabolic profile described by Equation (8). Although increased roughness significantly slows the water, other processes must also contribute to the drag.

Englacial passageways may significantly slow the water. One possible glacial structure is a crevasse, which is known to route surface water into the glacier interior. Crevasses are an appealing possibility because (1) they present a testable hypothesis; (2) water is often heard running in crevasses at South Cascade Glacier but the wall separation prevents probe widths of $10 \mathrm{~mm}$ from reaching the water, indicating a large surface-to-flow area ratio; (3) the tracers were generally injected into crevasses. Water flow through a crevasse is assumed to be analogous to laminar flow between parallel plates. From the Navier-Stokes equat-ions, the mean laminarflow velocity between parallel plates can be derived

$$
u_{\mathrm{v}}=\frac{\rho g}{12 \mu} w^{2} S
$$

where $\rho$ is water density at $0^{\circ} \mathrm{C}\left(10^{3} \mathrm{~kg} \mathrm{~m}^{-3}\right), g$ is gravity $\left(9.81 \mathrm{~m} \mathrm{~s}^{-2}\right), \mu$ is dynamic viscosity $\left(1.79 \times 10^{-3} \mathrm{~kg}\right.$ $\left.\mathrm{m}^{-1} \mathrm{~s}^{-1}\right), w$ is the separation distance between walls and $S$ is the slope of the water in the crevasse. Calculations based on Equation (12) indicated that crevasses may significantly slow the passage of water if the wall separation was a few millimeters.

Results from the analysis of flow condition and of channel characteristics indicate that englacial routing of water to the subglacial channel are important processes. 
Further, it is unlikely that any of the tracers were routed to the channel without some significant effect of these processes. This indicates that routing models of water flow that depend on one type of flow situation, such as a channel, do not reliably represent the true situation.

\section{TRACER DISPERSION IN DISTRIBUTED FLOW}

The concentration-time curves from the stream 2 basin are characterized by multiple peaks on a broadly dispersed curve (Fig. 3). This indicates that subglacial flow is a distributed system of flow paths. The paths may be conduits, subglacial debris bands of high permeability or linked cavities. To examine these different possibilities, the travel time was determined for the earliest tracer peak, the latest peak and the peak characterizing the average flow velocity (mean peak) of each concentrationtime curve. The geometric parameters for each flow system were then estimated for the set of travel times.

For a network of small subglacial conduits, it was assumed that the earliest peak was a result of flow in a conduit that followed a straight path between the injection location and stream exit, a conduit with a sinuosity of 1 . The velocity for the earliest peak was estimated from the distance and travel time. The radius of the conduit was estimated by re-arranging the flow equations for turbulent or laminar flow in pipes, assuming a circular cross-section, and given the estimated velocity, water slope (approximated by the bed slope) and Manning's $n$ (chosen to be 0.04 ). Once the radius was calculated, the water discharge was calculated. For the mean and late peaks, the radius was assumed to be the same as for the straight path and the sinuosities increased to match the estimated travel time to the observed travel time. The results indicate that the radius of the conduits is about $1 \mathrm{~mm}$ and the discharge in each conduit is about $10^{-7} \mathrm{~m}^{3} \mathrm{~s}^{-1}$. To account for the measured stream discharge, approximately $10^{6}$ conduits would have to exist and the width of all the conduits together would exceed the length under the stream 2 basin. Clearly, the observed concentration-time curve cannot result from a twodimensional network of conduits.

Based on field observations along the glacier margin, in natural ice tunnels and down moulins, much of the glacier in the stream 2 basin is underlain by debris. The water flux through the debris may be sufficient to account for the measured stream flow from the glacier. Because the tracers indicate preferred flow paths, however, the debris may not completely cover the bedrock or the debris is relatively impermeable in some locations and permeable in others. For simplicity, it is assumed that all the water is transported by relatively permeable interconnected bands of debris with impermeable zones in between. As in the previous analysis, earliest arrival time denotes flow in a path with a sinuosity of 1 . The velocity is estimated from the distance and travel time. The porosity is assumed to be 0.4 , a reasonable value for the size range of gravels and sands (Freeze and Cherry, 1979 , p. 36$)$. The hydraulic conductivity is then calculated by re-arranging Equation (10). The conductivity is kept constant and the sinuosity is calculated for the mean and late peaks.
The calculated hydraulic conductivity of the debris ranges from 0.5 to $1.0 \mathrm{~m} \mathrm{~s}^{-1}$ and represents the upper limit of measured conductivity for gravel (Freeze and Cherry, 1979, p. 29). The sinuosities for this system range from 1 to 2. To account for the measured stream discharge, the saturated debris would have to be about $0.05 \mathrm{~m}$ in depth and cover about $13 \%$ of the glacier bed. This result is plausible.

The subglacial water may flow through a network of interconnected cavities. The cavities envisioned are more or less stagnant and exist under ice a few tens of meters thick that is barely moving, unlike the cavities described by Kamb (1987). Evidence of a former cavity network has been observed on exposed bedrock near the glacier margins. The slowest water speed and hence most of the travel time through the cavity network is assumed to take place in the cavities, and the time through the connections between cavities can be ignored (Walder, 1986). It is difficult to estimate the geometry of subglacial cavities because the speed of the glacier in the stream 2 basin is unknown. For an initial estimate, the width of the cavities was assumed to approximate values derived from evidence of former cavities. The cavity width was assumed to be $0.3 \mathrm{~m}$ with a water depth of $0.05 \mathrm{~m}$. The water discharge through a cavity was arbitrarily assumed to be $10^{-3} \mathrm{~m}^{3} \mathrm{~s}^{-1}\left(11 \mathrm{~s}^{-1}\right)$. From the cross-sectional area of the cavity, water discharge and observed travel time, a total length of the cavities was calculated. Assuming that the cavities are oriented parallel to the elevation contours and the connections between cavities are perpendicular to the contours, the sinuosity of the path is calculated.

The results indicate as much as $9 \%$ of the glacier bed would have to be covered by cavities and the sinuosity would range from 1.6 to 5.1 for the early to late peaks. Of course, if the water flux decreases through some cavities compared to others, then the velocity would decrease and the sinuosity would be correspondingly smaller. Although the values for the cavity geometry and estimate of water flux are certainly ad hoc, it indicates in a qualitative way that flow in interconnected cavities can also reasonably explain the observed tracer curves from the stream 2 basin.

\section{CONGLUSIONS}

The dispersion of tracers can be used to distinguish qualitatively between channelized flow systems and distributed flow systems. Quantitative information about each flow system is more difficult to derive. The primary difficulty is the effect of englacial flow processes that route the water from the point of injection to the subglacial flow system. This subject has received little attention despite its significance to the interpretation of tracer results and interpretation of water levels in boreholes drilled to the glacier bed.

Insight into the processes of water flow through glaciers has been gained by comparing the empirical results to predictions from calculations based on physical principles. The change in the travel time relative to the change in water discharge, compared to that expected from Manning's equation, indicates whether the conduits are partly filled or pressurized. By keeping the primary 
dispersion processes of longitudinal advection and turbulent diffusion separate in the advection-diffusion equation, one can estimate the path length and flow geometry.

The tracer results from South Cascade Glacier indicate two main drainage basins, each with different flow processes. One basin that drains the accumulation zone and a part of the ablation zone into stream 3 has parallel-flow systems, one englacial and one subglacial. The englacial system is composed of an arborescent network of conduits in the upper ablation zone. The subglacial flow system is distributed with many divergent flow paths. The subglacial flow system is not well connected to the englacial and seems to be an independent flow regime. The two systems connect in the lower ablation zone to a subglacial conduit which appears at the terminus as stream 3 . That surface water does not readily reach the bed in the upper ablation zone has important implications for the dynamics of South Cascade Glacier.

The subglacial conduit in the lower ablation zone was pressurized in July and partly pressurized in August. An enlarging conduit may explain the change. The flow speed through the glacier is an order of magnitude slower than the estimated flow speed in the glacial conduits, indicating other, slower-flow processes are present. Most likely, englacial flow, which routes water to conduits, is slow compared to the flow in conduits.

The other basin drains the remainder of the ablation zone into stream 2. In this basin, the water flows in series from the englacial system to the subglacial system. The highly dispersive tracer curves, with individual spikes of high concentration, indicate a distributed flow system with multiple preferred flow paths. Qualitative analysis of the travel time of individual tracer peaks indicates that the flow system could be composed of linked subglacial cavities or paths of interconnected permeable debris.

\section{ACKNOWLEDGEMENTS}

During the field study G. Boyce, S. Frankenstein, C. Gemmell, B. Vaughn and R. Walters helped inject tracers and monitor their detection. Without their aid, much of this study would not have been possible. Conversations with J.D. Smith provided physical insight into the processes of tracer dispersion. The reviews of $\mathrm{K}$. Bencala, S. Burges, R. Hooke, C. Raymond and R. Walters helped to organize the paper and clarify the important arguments.

\section{REFERENCES}

Behrens, H., H. Bergmann, H. Moser, W. Ambach and O. Jochum. 1975. On the water channels of the internal drainage system of the Hintereisferner, Ötztal Alps, Austria. 7. Glaciol., 14(72), 375-382.

Bencala, K. E. and R.A. Walters. 1983. Simulation of solute transport in a mountain pool-and-riffle stream: a transient storage model. Water Resour. Bull., 19(3), 718-724.
Bencala, K.E., R.E. Rathburn, A. P. Jackman, V. C. Kennedy, G.W. Zellweger and R.J. Avanzino. 1983. Rhodamine WT dye losses in a mountain stream environment. Water Resour. Bull., 19(6), 943-950.

Brugman, M.M. 1986. Water flow at the base of a surging glacier. (Ph.D. thesis, California Institute of Technology, Pasadena, CA.)

Burkimsher, M. 1983. Investigations of glacier hydrological systems using dye tracer techniques: observations at Pasterzengletscher, Austria. f. Glaciol., 29(103), 403-416.

Chow, V.T. 1959. Open-channel hydraulics. New York, McGraw Hill.

Collins, D.N. 1982. Flow-routing of meltwater in an alpine glacier as indicated by dye tracer tests. Beitr. Geol. Schweiz. Hydrol., 28(2), 523-534.

Fischer, H. B., E.J. List, R. C. Y. Koh, J. Imberger and N. H. Brooks. 1979. Mixing in inland and coastal waters. New York, Academic Press.

Fountain, A.G. 1989. The storage of water in, and hydraulic characteristics of, the firn of South Cascade Glacier, Washington State, U.S.A. Ann. Glaciol., 13, 69-75.

Fountain, A.G. In pressa. Automatic system for measuring and recording fluorometric data from multiple sources. U.S. Geol. Surv. Water Supply Pap. 2340.

Fountain, A. G. In press b. Subglacial water flow inferred from stream measurements at South Cascade Glacier, Washington State, U.S.A. 7. Glaciol.

Freeze, R.A. and J.A. Cherry. 1979. Groundwater. Englewood Cliffs, NJ, Prentice-Hall.

Gaspar, E. 1987. Modern trends in tracer hydrology. Volume 1. Boca Raton, FL, CRC Press.

Hallet, B. and R.S. Anderson. 1980. Detailed glacial geomorphology of a proglacial bedrock area at Castleguard Glacier, Alberta, Canada. Z. Gletscherkd. Glazialgeol., 16(2), 171-184.

Hodge, S. M. 1979. Direct measurement of basal water pressures: progress and problems. F. Glaciol., 23(89), 309-319.

Holmlund, P. 1988. Internal geometry and evolution of moulins, Storglaciären, Sweden. F. Glaciol., 34(117), 242-248.

Hooke, R. LeB. 1984. On the role of mechanical energy in maintaining subglacial water conduits at atmospheric pressure. 7. Glaciol., 30(105), 180-187.

Hooke, R. LeB., S. B. Miller and J. Kohler. 1988. Character of the englacial and subglacial drainage system in the upper part of the ablation area of Storglaciären, Sweden. J. Glaciol., 34(117), 228-231.

Kamb, B. 1987. Glacier surge mechanism based on linked cavity configuration of the basal water conduit system. 7. Geophys. Res., 92(B9), 9083-9100.

Krimmel, R., W.V. Tangborn and M. F. Meier. 1973. Water flow through a temperate glacier. Association of Hydrological Sciences Publication 107 (Symposium at Banff 1972 - The Role of Snow and Ice in Hydrology), 401-416.

Lang, H., C. H. Leibundgut and E. Festel. 1981. Results from tracer experiments on the water flow through the Aletschgletscher. Z. Gletscherkd. Glazialgeol., 15(2), 1979, 209-218.

Nikuradse, J. 1933. Stromungsgesetze in rohen Rohren. 
VDI-Forschungsh. 361. Also in translation: NACA Tech. Memo. 1292.

Rattray, M., Jr and E. Mitsuda. 1974. Theoretical analysis of conditions in a salt wedge. Estuar. Coastal Mar. Sci., 2, 373-394.

Roberson, J.A. and C. T. Crowe. 1985. Engineering fluid mechanics. Third edition. Boston, MA, Houghton-Mifflin.

Röthlisberger, H. 1972. Water pressure in intra- and subglacial channels. J. Glaciol., 11(62), 177-203.

Scheidegger, A.E. 1974. The physics of flow through porous media. Third Edition. Toronto, University of Toronto Press.

Schommer, P. 1977. Wasserspiegelmessungen im Firn des Ewigschneefeldes (Schweizer Alpen) 1976. Z. Gletscherkd. Glazialgeol., 12(2), 1976, 125-141.

Schumm, S. A. 1977. The fluvial system. New York, John Wiley and Sons.

Seaberg, S. Z, J.Z. Seaberg, R. LeB. Hooke and D. W. Wiberg. 1988. Character of the englacial and subglacial drainage system in the lower part of the ablation area of Storglaciären, Sweden, as revealed by dye-trace studies. 7. Glaciol., 34(117), 217-227.

Shimizu, Y. 1989. Effects of lateral shear stress in open channel flow. Hokkaido. Hokkaido Development Bureau. (Publication 439.)

Shreve, R. L. 1972. Movement of water in glaciers. $\mathcal{J}$. Glaciol., 11(62), 205-214.

Shreve, R.L. 1985. Esker characteristics in terms of glacier physics, Katahdin esker system, Maine. Geol. Soc. Am. Bull., 96(5), 639-646.

Smart, C. C. 1988. Quantitative tracing of the Maligne karst system, Alberta, Canada. Hydrology, 98, 185-204.

Stenborg, T. 1973. Some viewpoints on the internal drainage of glaciers. Association of Scientific Hydrology Publication 95. (Symposium at Cambridge 1969 Hydrology of Glaciers), 117-129.

Taylor, G. 1953. Dispersion of soluble matter in solvent flowing slowly through a tube. Proc. R. Soc. London, Ser. A, 219, 186-203.

Vivian, R. 1980. The nature of the ice-rock interface: the results of investigation on $20000 \mathrm{~m}^{2}$ of the rock bed of temperate glaciers. 7. Glaciol., 25(92), 267-277.

Walder, J.S. 1986. Hydraulics of subglacial cavities. $\mathcal{J}$. Glaciol., 32(112), 439-445.

Walder, J. and B. Hallet. 1979. Geometry of former subglacial water channels and cavities. J. Glaciol., 23(89), 335-346.

Weertman, J. 1972. General theory of water flow at the base of a glacier or ice sheet. Rev. Geophys. Space Phys., 10(1), 287-333.

Wiberg, P. L. and J.D. Smith. 1987. Calculations of the critical shear stress for motion of uniform and heterogeneous sediments. Water Resour. Res., 23(8), 1471-1480.

Willis, I. C., M.J. Sharp and K.S. Richards. 1990. Configuration of the drainage system of Midtdalsbreen, Norway, as indicated by dye-tracing experiments. 7. Glaciol., 36(122), 89-101.

The accuracy of references in the text and in this list is the responsibility of the author, to whom queries should be addressed. 